\title{
Examination of Surface Finish in Burnishing of Brass and Copper
}

\author{
Kundan Kumar D, B. Rajendra Prasad, Vikash Kumar, Eshwara Prasad Koorapati
}

\begin{abstract}
Fine machining process of cylindrical surfaces exposed to the high exploitation loadings has to ensure acceptable surface quality and it's longer functionality. Quality of surface is an important factor to decide the performance of a manufactured product. The main aim of this research work is to analyse the impact of roller burnishing operation on the cylindrical work material, directed to achieving smaller roughness of test specimens. Roller burnishing is a fine machining process that is used to improve certain physical and mechanical properties. The common parameters in this work selected for burnishing process is to determine and analyse surface roughness. The process parameters considered for roller burnishing process are tool material, force applied and the number of tool passes. The Roller burnishing tool is made of high carbon steel, the burnishing operation is done on copper and brass specimens with different burnishing forces which are varying from 1 to 6 burnishing tool passes. The surface roughness of the specimens was measured before and after burnishing by using surface roughness tester. It has been observed from the surface roughness $R a$.
\end{abstract}

KEYWORDS: Roller Burnishing, Brass, Copper and Surface finish.

\section{INTRODUCTION}

After the turning operations the surface roughness of the samples has been measured using the surface roughness measuring instrument. The surface roughness values have been tabulated for each material.

Table 1 Surface roughness values of specimens considered

\begin{tabular}{|l|l|l|l|}
\hline Si. No & $\mathbf{R a}(\mu \mathrm{m})$ & $\mathbf{R q}(\mu \mathrm{m})$ & $\mathbf{R z}(\mu \mathrm{m})$ \\
\hline Copper & 2.016 & 2.439 & 11.82 \\
\hline Brass & 2.369 & 2.863 & 12.85 \\
\hline
\end{tabular}

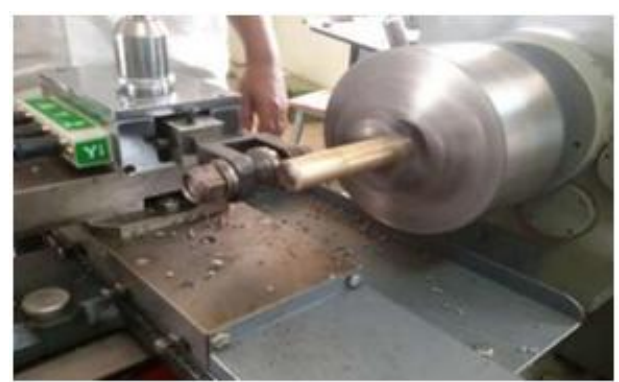

Fig. 1 Pictorial view of experimental set-up

Revised Manuscript Received on December 22, 2018.

Dr. Kundan Kumar D, Dept. of Mechanical Engineering, Malla Reddy College of Engineering, Maisammaguda, Dhulapally, Kompally, Secunderabad-100, Telangana, India.

Mr. B. Rajendra Prasad, Dept. of Mechanical Engineering, Malla Reddy College of Engineering, Maisammaguda, Dhulapally, Kompally, Secunderabad-100, Telangana, India.

Mr. Vikash Kumar, Dept. of Mechanical Engineering, Malla Reddy College of Engineering, Maisammaguda, Dhulapally, Kompally, Secunderabad-100, Telangana, India.

Dr. Eshwara Prasad, Dept. of Mechanical Engineering, Malla Reddy Secunderabad-100, Telangana, India. College of Engineering, Maisammaguda, Dhulapally, Kompally,

\subsection{Surface roughness test after burnishing:}

By using the surface roughness measuring equipment the surface roughness is determined after burnishing.

The variation of surface roughness with number of burnishing passes is studied keeping the other burnishing conditions (speed, feed and force) constant and the results are shown in table 1 to 4 .

It is observed that surface hardness increases with increase in the burnishing force. This is mainly due to the increased plastic deformation of micro irregularities with high burnishing forces. There is an optimum burnishing force, beyond which the surface hardness decreases.

\section{LITERATURE REVIEW}

Higher work hardening of surface layer will lead to flaking effect, which is the main cause for decrease in surface hardness with higher and higher burnishing forces. The burnishing force which gives maximum surface hardness for test specimens by roller burnishing operation at a speed of $0.5 \mathrm{~m} / \mathrm{s}$ and feed of $0.1 \mathrm{~mm} / \mathrm{rev}$ and different forces has been measured keeping speed and feed are constant.

It is observed from the graph that maximum reduction in surface roughness is observed in the first five passes. Beyond five passes, there is not much improvement in the surface finish in the present experiment.

In each number of pass, the burnishing force is being applied on the deformed asperities of the previous operation. Then, there will be a further deformation in the asperities in each number of pass thereby the surface roughness will decrease with number of passes.

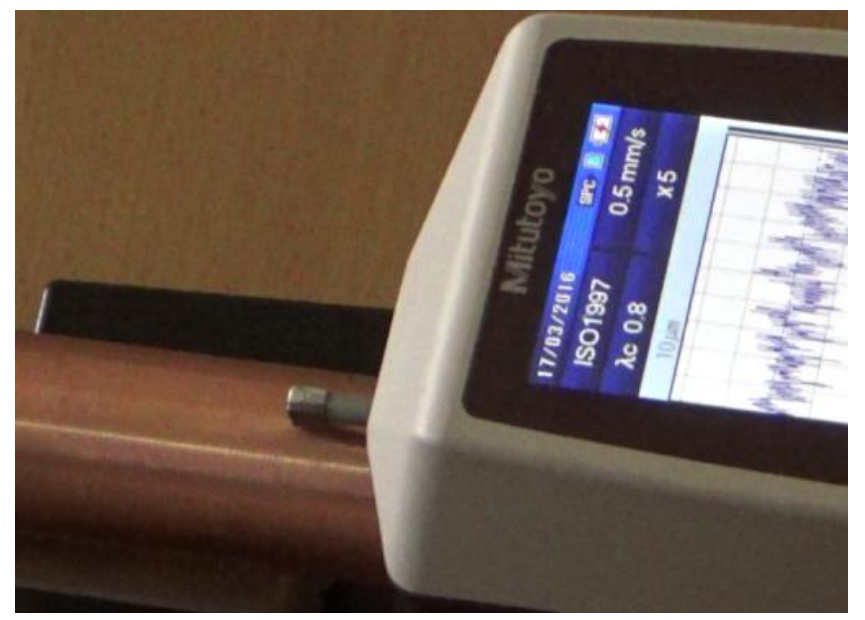

Fig 2 Surface roughness measurement

The variation of surface hardness with burnishing force is shown in table for brass and copper by roller burnishing.

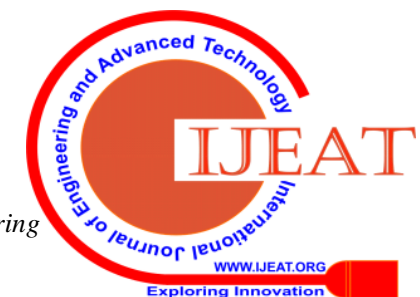




\section{RESULTS AND DISCUSSIONS:}

Table 2 Surface roughness values of copper specimens measured after burnishing at different burnishing forces

\begin{tabular}{|c|c|c|c|c|}
\hline \multicolumn{5}{|c|}{ Surface Roughness, $\mathrm{Ra}(\mu \mathrm{m})$} \\
\hline $\begin{array}{c}\text { No of } \\
\text { Tool } \\
\text { Passes }\end{array}$ & $\begin{array}{c}\text { At } \\
\text { Burnishing } \\
\text { force=34.4 } \\
\mathrm{N}\end{array}$ & $\begin{array}{c}\text { At } \\
\text { Burnishing } \\
\text { force=40.9 } \\
\mathrm{N}\end{array}$ & $\begin{array}{c}\text { At } \\
\text { Burnishing } \\
\text { force=47.3 } \\
\mathrm{N}\end{array}$ & $\begin{array}{c}\text { At } \\
\text { Burnishing } \\
\text { force=56.9 } \\
\mathrm{N}\end{array}$ \\
\hline 1 & 1.253 & 1.047 & 0.847 & 0.813 \\
\hline 2 & 0.905 & 0.847 & 0.721 & 0.697 \\
\hline 3 & 0.776 & 0.703 & 0.618 & 0.567 \\
\hline 4 & 0.957 & 0.867 & 0.753 & 0.698 \\
\hline 5 & 1.038 & 0.994 & 0.802 & 0.757 \\
\hline 6 & 1.108 & 1.057 & 0.857 & 0.819 \\
\hline
\end{tabular}

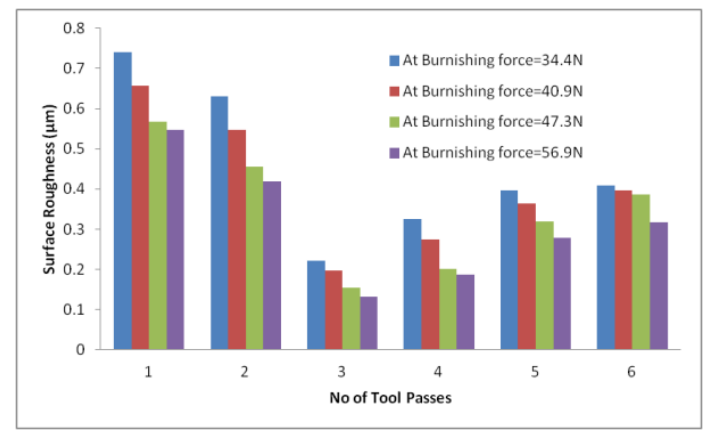

Fig. 3 Variation of surface roughness after burnishing for different number of passes

Table 3: Percentage increase in surface finish values of copper specimens after burnishing at different burnishing forces

\begin{tabular}{|c|c|c|c|c|}
\hline \multicolumn{5}{|c|}{$\%$ increase in surface finish } \\
\hline $\begin{array}{c}\text { No of } \\
\text { Tool } \\
\text { Passes }\end{array}$ & $\begin{array}{c}\text { At } \\
\text { Burnishing } \\
\text { force=34.4N }\end{array}$ & $\begin{array}{c}\text { At } \\
\text { Burnishing } \\
\text { force=40.9N }\end{array}$ & $\begin{array}{c}\text { At } \\
\text { Burnishing } \\
\text { force=47.3N }\end{array}$ & $\begin{array}{c}\text { At } \\
\text { Burnishing } \\
\text { force=56.9N }\end{array}$ \\
\hline 1 & 37.85 & 48.07 & 57.99 & 59.67 \\
\hline 2 & 55.11 & 57.99 & 64.24 & 65.43 \\
\hline 3 & 61.51 & 65.13 & 69.35 & 71.88 \\
\hline 4 & 52.53 & 56.99 & 62.65 & 65.38 \\
\hline 5 & 48.51 & 50.69 & 60.22 & 62.45 \\
\hline 6 & 45.04 & 47.57 & 57.49 & 59.38 \\
\hline
\end{tabular}

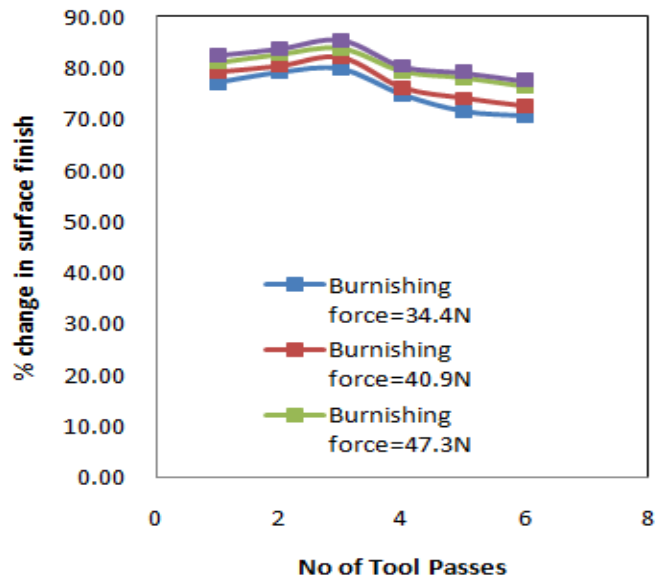

Fig. 4 Percentage of change in surface finish for different number of passes
From figures 3 it is found that the surface roughness (Ra) value decreased more for copper specimen when burnishing was done on the specimens for number of tool passes equal to three, when compared with remaining. The surface roughness (Ra) value varied from 2.016 to $0.567 \mu \mathrm{m}$. The percentage of increase in surface roughness was close at burnishing forces $47.3 \mathrm{~N}$ and $56.9 \mathrm{~N}$ as shown in figure 4 .

Table 4 Surface roughness values of brass specimens measured after burnishing at different burnishing forces

\begin{tabular}{|c|c|c|c|c|}
\hline \multicolumn{5}{|c|}{ Surface Roughness, $\operatorname{Ra}(\mu \mathrm{m})$} \\
\hline $\begin{array}{c}\text { No of } \\
\text { Tool } \\
\text { Passe } \\
\text { s }\end{array}$ & $\begin{array}{c}\text { At } \\
\text { Burnishi } \\
\text { ng } \\
\text { force }=34 \\
.4 \mathrm{~N}\end{array}$ & $\begin{array}{c}\text { At } \\
\text { Burnishi } \\
\text { ng } \\
\text { force }=40 \\
.9 \mathrm{~N}\end{array}$ & $\begin{array}{c}\text { At } \\
\text { Burnish } \\
\text { ing } \\
\text { force }=4 \\
7.3 \mathrm{~N}\end{array}$ & $\begin{array}{c}\text { At } \\
\text { Burnish } \\
\text { ing } \\
\text { force }=5 \\
6.9 \mathrm{~N}\end{array}$ \\
\hline 1 & 0.539 & 0.491 & 0.447 & 0.416 \\
\hline 2 & 0.492 & 0.464 & 0.409 & 0.387 \\
\hline 3 & 0.476 & 0.424 & 0.381 & 0.347 \\
\hline 4 & 0.597 & 0.564 & 0.487 & 0.467 \\
\hline 5 & 0.676 & 0.612 & 0.517 & 0.496 \\
\hline 6 & 0.698 & 0.649 & 0.557 & 0.534 \\
\hline
\end{tabular}

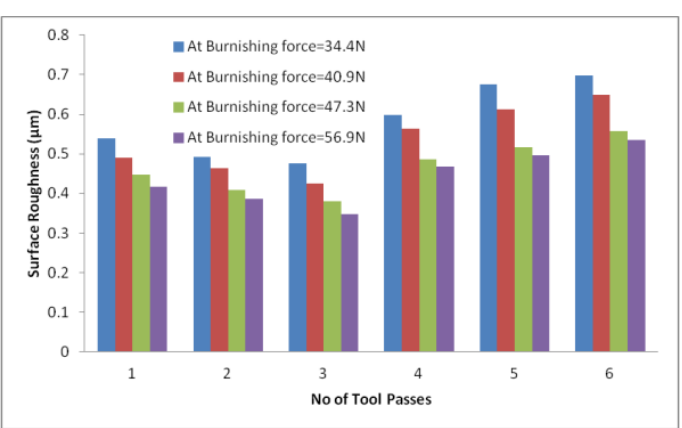

Fig. 5 Variation of surface roughness after burnishing for different number of passes

Table 5 Percentage increase in surface finish values of brass specimens after burnishing at different burnishing forces

\begin{tabular}{|c|c|c|c|c|}
\hline \multicolumn{5}{|c|}{$\%$ increase in surface finish } \\
\hline No & At & $\overline{\mathrm{At}}$ & $\overline{\mathrm{At}}$ & $\overline{\mathrm{At}}$ \\
\hline of & Burnis & Burnish & Burnishin & Burnish \\
\hline Tool & hing & ing & & in \\
\hline Pass & force $=$ & force $=4$ & force $=47$. & force $=5$ \\
\hline es & $34.4 \mathrm{~N}$ & $0.9 \mathrm{~N}$ & $3 \mathrm{~N}$ & $6.9 \mathrm{~N}$ \\
\hline 1 & 77.25 & 79.27 & 81.13 & 82.44 \\
\hline 2 & 79.23 & 80.41 & 82.74 & 83.66 \\
\hline 3 & 79.91 & 82.10 & 83.92 & 85.35 \\
\hline 4 & 74.80 & 76.19 & 79.44 & 80.29 \\
\hline 5 & 71.46 & 74.17 & 78.18 & 79.06 \\
\hline 6 & 70.54 & 72.60 & 76.49 & 77.46 \\
\hline
\end{tabular}




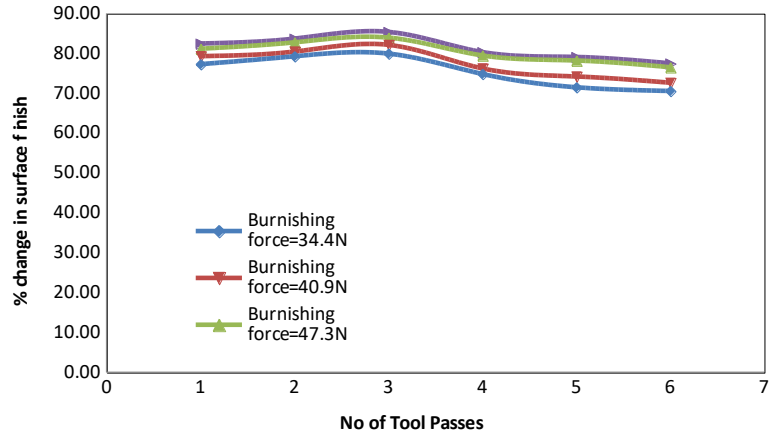

Fig. 6 Percentage of change in surface finish for different number of passes

It has been identified from the figures 4 , that the surface roughness $(\mathrm{Ra})$ value decreased more for brass specimen from 2.369 to $0.347 \mu \mathrm{m}$ at number of tool passes equal to three. From figure 5, the increase in percentage of surface finish value is very close for burnishing forces $47.3 \mathrm{~N}$ and $56.9 \mathrm{~N}$. There was very less change in specimens when burnished at number of passes equal to three at burnishing forces $47.3 \mathrm{~N}$ and $56.9 \mathrm{~N}$.

After a certain number of passes, as the surface layer is highly work hardened due to repeated contact of the tool, further deformation of asperities at the same burnishing force is not so considerable. Thereby, there is not much improvement in surface finish after a certain number of passes.

\section{CONCLUSIONS}

The Roller burnishing tool is made of high carbon steel, the burnishing operation is done on aluminium, copper, brass and mild steel specimens with different burnishing forces which are varying from 1 to 6 burnishing tool passes.

The surface roughness of the specimens was measured before and after burnishing by using MITYOTO surface roughness tester. It has been observed from the surface Roughness Ra.

The surface roughness of aluminium specimens had a maximum increase in surface roughness at three burnishing tool passes. The aluminium specimen surface roughness improved to maximum at peening pressure of $0.207 \mathrm{MPa}$. The shot peening process was done at three different peening pressures of $0.138 \mathrm{MPa}, 0.207 \mathrm{MPa}$ and $0.276 \mathrm{MPa}$. The peening operations were done on turned aluminium, copper, brass and mild steel specimens. The size of the ball diameter was $0.1 \mathrm{~mm}$ was used for shot peening process. The aluminium, copper, brass and mild steel specimen surface roughness improved to maximum at peening pressure of 0.207MPa. The six samples of aluminium, brass, copper and mild steel are measured to determine the longitudinal and transverse residual stresses. Residual stresses induced in the specimens after the burnishing and shot peening surface finish process; it was observed that the longitudinal and transverse stresses increase across the depth of the

specimens. Maximum stresses were found at contact of the burnishing tool and shot peens.178 Radiography test was conducted on the burnished specimens and shot peened specimens. Both the two surface finishing processes have not generated any defects or cracks in the specimens. Micro structure of burnished specimens and shot peened specimens are determined. Due to increase in amount of cold working process leads to increase in material flow to valleys. Maximum burnishing force increases rate of surface hardness which tends to mitigate depends on decreased generating rate of new dislocations at high level. The amount of work hardening is relatively low due to low improvement of surface hardness and high residual stresses existing in surface layers.

\section{REFERENCES}

1. Adam Charchalis, Robert Starosta, Wojciech Labuda, "The analysis of finish tooling influence on contact fatigue of steel applied to sea water pump shafts", Journal of Kones Power Train and Transport, 2011; 18(2): 85-92.

2. K. Saraswathamma, G. Venkateswarlu, S. Venkatarami Reddy, “ Optimization of surface roughness in the Roller burnishing process using response surface methodology and desirability function, International conference on Emerging Trends in Mechanical Engineering ICEME-2014, ISBN: 978-93-82163-09-1, 2014; 1.

3. Hussein Mesmari, Ibrahim el Bukhari, "Investigation on internal roller burnishing process of al- 2024-t361 surface roughness and microhardness characteristics, international journal of advanced technology \& engineering research, issn no: 2250-3536, 2014; 4(6): $1-9$.

4. Kumar, V., Prasad, L., Experimental investigation on heat transfer and fluid flow of air flowing under three sides concave dimple roughened duct. International Journal of Mechanical Engineering and Technology (IJMET), Volume 8, Issue 11, November 2017, pp. 1083-1094, Article ID: IJMET_08_11_110.

5. Kumar, V., Prasad, L., Thermal performance investigation of one and three sides concave dimple roughened solar air heaters. International Journal of Mechanical Engineering and Technology (IJMET) Volume 8, Issue 12, December 2017, pp. 31-45, Article ID: IJMET_08_12_004.

6. Kumar, V., Prasad, L., Performance Analysis of three sides concave dimple shape roughened solar air heater, J. sustain. dev. energy water environ. syst., 6(4), pp 631-648, 2018.

7. Kumar, V., Nusselt number and friction factor correlations of three sides concave dimple roughened solar air heater, Renewable Energy 135 (2019) 355-377.

8. Kumar, V., Prasad, L., Experimental analysis of heat transfer and friction for three sides roughened solar air heater, Annales de Chimie - Science des Matériaux, 75-107, ACSM. Volume 41 - n 1-2/2017.

9. Kumar, V., Prasad, L., Performance prediction of three sides hemispherical dimple roughened solar duct, Instrumentation, Mesure, Métrologie, 273-293 I2M. Volume $17-\mathrm{n}^{\circ}$ 2/2018.

10. Grzesik, Krzysztof Zak, "Comparison of surface textures produced by finish cutting, abrasive and burnishing operations in terms of their functional properties", Journal of Machine Engineering, 13(2): 2013; 46-58.

11. Kundan K. Dande, Dr. Eshwara P. Koorapati., 2018 Parametric Analysis Of Surface Finish In Burnishing And Shot Peening Process. World Journal of Engineering Research and Technology 4(2), pp 498 504.

12. Kundan K. Dande, Dr. Eshwara P. Koorapati., 2015 Application of Roller Burnishing Process for Final Machining Of Cilindrical Surface. IOSR Journal of Mechanical and Civil Engineering 12(1), pp 01-07

13. Kundan K. Dande, Dr. Eshwara P. Koorapati., 2015 The Effects of Shot Peening on the Fatigue Life of machine Elements. International Journal of Mechanical Engineering 43(1), pp 1269-1273.

14. Kundan K. Dande, Dr. Eshwara P. Koorapati., 2015 Surface Roughness and Residual Stresses of the Roller Burnishing Process on Aluminum A2014. International Journal Of Advances in Engineering and Management 2(1), pp 202205 . 
15. Kundan K. Dande, Dr. Eshwara P. Koorapati., 2015 Pan Experimental Work On Multi-Roller Burnishing Process On Aluminum Alloy. International Journal Of Advances In Production And Mechanical Engineering (Ijapme) 1(4), pp 24-28.

16. Kumar, M., Murty, A., Godine, Y., Adamu, T., \& Kumar, D. (2015). The Feasibility Study Of Wind Power Genertion Over Arbaminch, Ethiopia. Journal of Applied Physical Science International, 5(4), 213-219. Retrieved http://www.ikprress.org/index.php/JAPSI/article/view/3235

17. J. T. Maximov1, G. V. Duncheva, I. M. Amudjev3, K. K. Krumov4 and T. V. Kuzmanov, "A new single-roller burnishing technique decreasing roughness obtained", journal of materials science and engineering with advan ced technology, 2010; 2(2): 177-201. 